\title{
Dynamics in Nigerian Land Administration System and the Inevitability of Decentralization
}

\author{
Madumere Nelson \\ School of Business and Law, University of East London, London, United Kingdom \\ nellyking406@yahoo.com
}

\begin{abstract}
The heterogenous nature of the Nigerian society underscores the emergence of pluralistic legal and land administration system. An evaluation of the historical synopsis of the Nigerian land administration system and reforms reveal the inevitability of statutory recognition of these practical realities and their implications. The adoption of the Nigerian Land Use Act of 1978 and its land nationalization agenda implied a sharp deviation from the status quo. Understandably, this policy choice was informed by the need to provide lasting solution to problems associated with pluralistic legal and land administration systems in Nigeria. However, the continued existence of these problems and the emergence of fresh constraints clearly underscore the ineffectiveness of this policy choice to the achievement of desired goals, particularly as it relates to customary tenurial arrangements. Thus, the urgent need for a paradigm shift. In respect of above concerns, this paper develops a novel and decentralized land administration model along the pre-existing zonal blocs; reflective of practical realities and social dynamics of the Nigerian state. Such would provide for the eventual adoption of innovative, more realistic and zone-specific land administration system reflective of practical realities and social dynamics of the Nigerian state, thereby providing equitable and secure land rights for all Nigerians.
\end{abstract}

Keywords: Legal pluralism, customary law, land administration, sustainable development, land reform, tenure security, decentralization

\section{Introduction}

An examination of the narratives leading to the prevailing land tenure and administration system in Nigeria from a historical perspective is desirable to unravel the reasons behind the perceptions towards land, its uses, access, value and administration in Nigeria, as well as why calls for land reform continues to reverberate across the length and breadth of the Nigerian landscape despite the recent Supreme Court's clampdown on inequitable and discriminatory land practices (Ukeje v. Ukeje (2014) 3-4 MJSC 149; Anekwe v. Nweke (2014) 3-4 MJSC 183) and various efforts previously depicted towards land matters by both the colonial and post-colonial administrations in Nigeria.

Land administration entails the "process of determining, recording and disseminating information about ownership, value and use of land and its associated resources. These processes include the determination (sometimes called 'adjudication') of land rights and other attributes, surveying and describing these, their detailed documentation, and the provision of relevant information for supporting land markets" (Williamson, Ian Philip, 2000). Many land administration reforms have been carried out in Nigeria with varying outcomes and implications. The heterogenous nature of the country precipitated the existence of pluralistic tenure arrangements in attempts to accommodate, respect and preserve the definitive characteristics and the socio-cultural, ethno-tribal, linguistic and religious divides that characterize the Nigerian state. Thus, four major distinctive forms of land administrative and tenurial systems were operational in Nigeria prior to the introduction of the land nationalization and unification exercise which gave birth to the Land Use Act of 1978. These were the tenurial arrangements under the Received English Law, tenurial rights under the State Land Law, Tenurial rights under the Land Tenure Law, and finally the indigenous tenurial rights under the customary law. Whereas two of the above tenurial arrangements had nationwide applicability, the other two conformed to the North-South dichotomy that characterized Nigerian state (Oshio 1990, 44). 


\section{Historical perspective on land administration in Nigeria}

A look down the historical lane reveals the actions and developments that shaped land administration and tenure arrangements in Nigeria. The Uthman Dan-Fodio led jihadist war of conquest which was unleashed upon the Hausa tribe of the northern part of the present-day Nigeria by the Fulani invaders between 18041810 disrupted the indigenous customary tenure system of the indigenous Hausas. Following this Islamic conquest, feudal tenure arrangements were imposed on the indigenous Hausa communities and the Sharia law principles were introduced as Fulani emirate established their lordship over the conquered lands under the leadership of the Emirs. However, following the formal establishment of the British colonial government's authority over the then Northern protectorate in 1900 and the introduction of the Crown Lands Proclamation Ordinance of 1902, all lands originally acquired by the Royal Niger Company (the body responsible for the administration of Northern Nigeria prior to the establishment of direct administrative rule over the territory by the British colonial authority in 1900) were ceded to the British colonial authority and were known as Crown lands. While the lands previously administered by the Fulani Emirs were also expropriated by the colonial administration and classified as Native Lands. This position was consolidated via the Land and Native Rights Proclamation of 1910. Meanwhile, whereas the Governor holds all Crown land in trust for Her Majesty's government, native Lands were to be administered for the benefit of the Natives. These ordinances were later amended in 1916 and indigenised by the Northern parliament in 1962 after the Nigerian independence of 1960 (Kunle n.d., 8-10). Section 6 of this 1962 land law vested the power to grant rights of occupancy to natives on the minister (Laws of Northern Region of Nigeria, 1963, Ch. 59). By virtue of this law, any one whose father was not from any of the indigenous tribes within the northern Nigerian enclave is regarded as a non-native (Oshio 1990, 46). This position remained operational within the northern Nigerian region until the introduction of the Land Use Act in 1978.

Land matters in Southern part of Nigeria were regulated by the customary legal provisions deeply rooted in the customs and traditions of the people. It should be noted that lands within the southern Nigeria has both economic, socio-political and religious connotations as it is regarded by the people as a sacred gift from God for the good and maintenance of all members of the communities dead or alive. Thus, it is generally believed that "land belongs to a vast family of which many are dead, few are living, and countless members are still unborn" (Awari n.d., 1). The living only hold land in trust for the benefit of their dead ancestors, themselves and generations yet to come.

Thus, it was unthinkable that such a sacred gift of nature and veritable asset with complex web of ownership arrangements could be entrusted in the hands of single individuals whom circumstances, or greed may compel to dispose of parts of the assets to solve personal challenges or for personal aggrandizement thereby depriving unborn generations their future source of livelihood and survival. There exist therefore mythical connotations to the idea of inalienability of land with the intent to protect people's common heritage. It was considered a taboo and serious violation against departed ancestors whose spirit lay buried in the soil to sell the land, and an act of unwisdom to deficit the interest of the unborn (Awari n.d., 2)

In recognition of the above belief, and the high premium placed on community interrelationships, extended family lineages and kingship, land rights were vested on communities, villages and kingships, and never on individuals. This customary attribute was given legal backing in Amodu Tijani v. Secretary of Southern Nigeria (1921) AC 399, 404, in which Viscount Haldane, in a bid to clarify and validate the status of the customary tenure system stated that "... the notion of individual ownership is quite foreign to native ideas. Land belongs to the community, the village or the family, never to the individual". Alienation of land was foreign to the ideas, customs and traditions of the olden society. Therefore, rights of individuals over land was limited to use and the enjoyment of same only. No individual has the right to alienate any part of the land thereof in whatsoever form without the requisite consent of the village or family representatives (Lewis v. Bankole (1909) 1 N.L.R 82, Eze v. Igiliegbe \& Ors., 14 WCA 61).

Heads of the families and communities were charged with the responsibilities of managing lands and exercising rights of ownership on behalf of the families and communities, and in some loose characterization, are often referred to as the owners. However, their positions are just like that of 
trustees, but not in the capacity trustees are perceived within the English law concept. Members of the families or communities with need for land for agricultural or residential purposes approach the heads of the families or communities for the permission to use the land. Such rights were legally recognized, and where a member of the family or community feels that such a right has been unreasonably denied, the person is at liberty to approach the court for redress (Oludayo, 2011, 61). The ownership of these lands can never either by effluxion of time or under any circumstances be divulged from the group to become personal property of the members of these groups. The heads of the families or chiefs of the communities cannot dispose of any piece of land thereof without consulting the elders of the groups, particularly, when such permissions were to be granted to strangers as customary tenants (Oshio 1990, 47). This idea of preserving land within the family and community units and its inalienability outside the confines of these allodial groups led to the emergence of different other subsidiary interests in land through which strangers and migrants could be allowed access to land for cultivation and dwelling under special arrangements. Thus, families and communities prefer to give out their land to outsiders to use after observing some customary rights as the radical ownership right remain with the family or community. This informed the emergence of some distinctive customary land ownership arrangements like the customary tenancy, kola tenancy and host of others.

At the assumption of direct rule over Nigeria by the British colonial authority in 1900, the colonial government also introduced the Native Land Acquisition Proclamation law of 1900 in southern Nigeria. In line with the discriminatory customary principle that abhors foreigners' right to acquire land, this law also barred foreigners from acquiring interest in land from natives and aliens alike except through the written approval of the Governor. The difficulty also encountered by the colonial government in their attempts to acquire lands for public and developmental purposes because of the customary principle of inalienability of land, particularly to aliens, led to the enactment of the Land Acquisition Ordinance (No. 9) of 1917 which gave the colonial government the right to compulsorily acquire land for public purposes (Dada 2010, 12)This marked the introduction of the doctrine of "eminent domain" in Nigerian legal system; a concept that is still generating controversies in Nigeria till date as subsequent Nigerian governments often hide under its clauses to expropriate people's land without commensurate compensations.

\section{Land Administration Reforms in Nigeria - A Brief Overview}

The high labour migrations resulting from colonial activities and developments brought about unprecedented transformations which could not be sustained without land being alienated to strangers. As the society evolved over time, and political cum economic factors joined forces with colonial experimentations to shaped and re-shaped the environment, customary restrictions on land transfer to foreigners waned as private land ownership evolved. Thus, land gradually became alienable to foreigners in southern Nigeria, though collective ownership of land remained more prevalent (Oshio 1990, 49). Unfortunately, some unscrupulous heads of families and community leaders usurped the opportunity presented by this development and started alienating group lands under their trust for their personal aggrandizements (Elias 1981, 72-73). Greed and racketeering became the order of the day as land speculators flood the market with dubious offers and manipulative entrapments. Litigations and land disputes increased and sale of same land to many unsuspecting buyers became rampant. Some people resort to violent acts in attempt to maintain their interests in land. There was also the problem of land fragmentation mainly occasioned by the customary right of inheritance which allows for the devolution of land to the deceased heirs at the demise of the land owner. The prohibitive cost of acquiring land by the government for public uses led to the promulgation of the Public Lands Acquisition (Miscellaneous Provision) Decree of 1978 to facilitate cheaper ways for government to acquire the desired land for public use and developments. However, the accompanying litigations, disputes and communal clashes that follow acquisitions based on leverages provided by the above decree often reduce such acquisitions to a pyrrhic accomplishment. (Dada 2010, 13-14).

Neither lands in the Northern part of Nigeria with a different tenure system nor public lands were immune to these corrupt onslaughts and callous profiteering. Governors dispossess members of the public of their lands and vest same on their preferred private individuals in contravention of the 
statutory guidelines (Ereku v. Military Governor of Mid-western state (1974) 4 All NLR 695). Rich and powerful members of the society used their positions to forcefully and dubiously rob the poor and less privileged northerners of their lands (Jegede 1981, 37)

Above developments made land reform inevitable and compelled the then military government of Nigeria to institute a Land Use Panel of enquiry to ascertain the remote and immediate causes of the problems bedeviling land administration and transactions in Nigeria with the aim of making appropriate recommendations (Okpala 1982, 574). The outcome of this panel informed the enactment of the Land Use Decree of 1978. However, it must be noted that though the majority report of this panel warned against the possible unification of land administration system in Nigeria, the government acting on the minority report, unified and nationalized all land in Nigeria through the Land Use Decree of 1978. This Decree was later re-designated an "Act" and was subsequently entrenched into the 1999 Constitution of the Federal republic of Nigeria, thus making an ordinary statute extra-ordinary (Smith 2007, 472-473).

Four decades after the promulgation of the Act, the actualization of its set objectives remain a mirage. Instead of solving the problems and challenges it met on ground, the Act has exacerbated some of the problems and created new ones. Population growth, property market development and urban encroachment, increase in competing demands for land for conservation, developments, agriculture and pastoralism, natural disasters like draught, flooding and desert encroachments, population mobility, globalization and its resultant corporate investments in land by international investors and many other emerging factors have jointly placed more pressure on available land, thus making land in Nigeria increasingly more contentious.

However, the biggest challenge to the Act manifests in its inability to address and reconcile issues relating to customary tenurial arrangements that exists within the Southern parts of Nigeria. These customary tenure holdings, particularly, the customs and traditions of the Igbo people of the Eastern Nigeria is characterized by complex and overlapping tenurial arrangements which evolved through centuries of customary transactions and experimentations. Some of its definitive elements seem too complex, dynamic and vague for modern statutory tenure system to comprehend and accommodate. Tenure relations of this nature remain readily available in many rural communities and constitute the bulk of the land rights mostly available to many low-income earners, rural dwellers and vulnerable members of the society like women and children. Proclivity to conventional reform approaches and judicial interventions have also failed to usher in the much-needed reprieve and sustainable remedy to the land administration and tenure constraints (Madumere 2017). Unfortunately, these forms of customary land rights often remain unrecognized by the conventional land administration systems despite the important functionalities and their ability to provide various degrees of tenure security to the practitioners who are obviously in the majority (Chigbu et al. 2017, 1), and the chances of the prevailing paradigm scaling up to engage those excluded by the status quo is marginal. The obvious dysfunctional and ineffectiveness of the prevailing land administration system in Nigeria re-enforces the call for urgent reforms and adoption of workable, innovative, fit-forpurpose and responsible land reform approaches reflective of socio-cultural dynamics and peculiarities of the Nigerian state.

The first step towards realization of this goal lies in the adoption of decentralized land administration system, as against the current centralized format imposed by the Act. This will require the amendment of the extant laws and subsequent removal of the Land Act from the Nigerian constitution. Such decentralization would enable constituent units of the Nigerian state to formulate land administration policies and frameworks reflective of their socio-cultural, economic, religious, environmental and geographic peculiarities, in relation to available resources and associated challenges.

\section{Prospects for Decentralised Land Administration System in Nigeria}

It will be impossible to devolve land administrative responsibilities along every ethno-tribal and religious divide of the heterogenous Nigerian State because of the vastness and similarities of the ethnic groups and contestations over the actual number of ethno-tribal divides in Nigeria. Fortunately, the existence of six 
Geo-Political Zones propounded by former Vice President Dr. Alex Ekwueme as antidote to ethnic domination concerns in Nigeria adopted during the 1994 Constitutional Conference would save the pain and responsibility of formulating new administrative blocs for the proposed devolvement of land administration responsibilities. Various political and economic fortunes of the Nigerian state are currently being determined and shared along these zones blocs. (Abdallah et al. 2017). Although known as "Geopolitical Zones", geographical considerations were not the basic factor that determined the constituents of each of the zones, rather socio-cultural, tribal, religious and traditional history and similarities of the component units. Of course, states, tribes or ethnic groups ordinarily need to share common boundaries to be grouped together.

Fig. i: Proposed Structural Framework for Land Administration Decentralization in Nigeria

\section{NATIONAL LAND AND NATURAL RESOURCES MANAGEMENT AND ADMINISTRATIVE AUTHORITY}
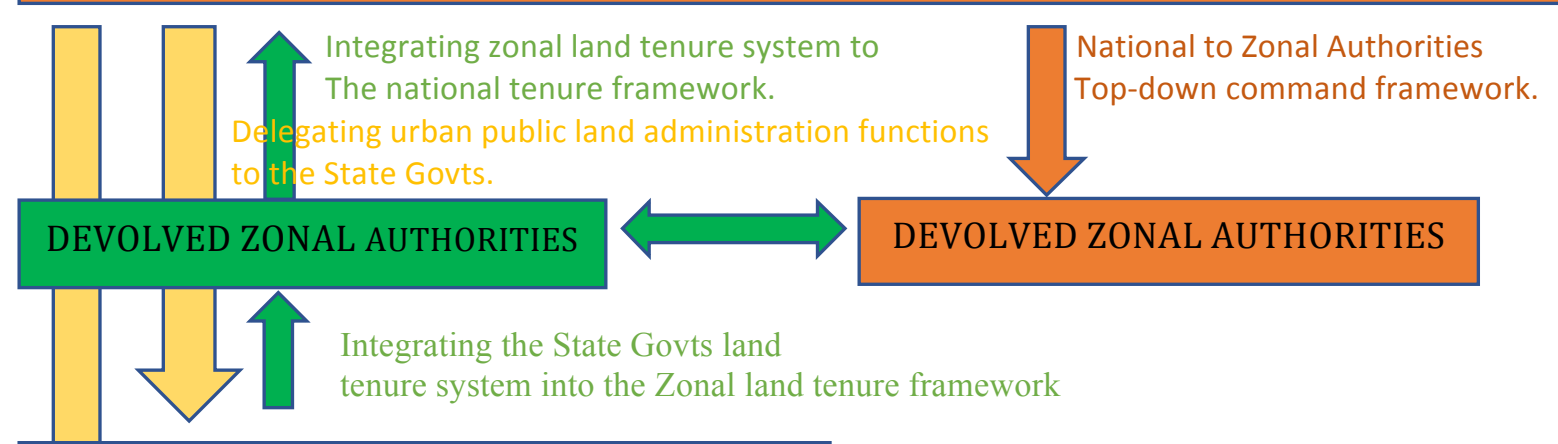

\section{STATE GOVERNMENTS LAND AUTHORITIES}

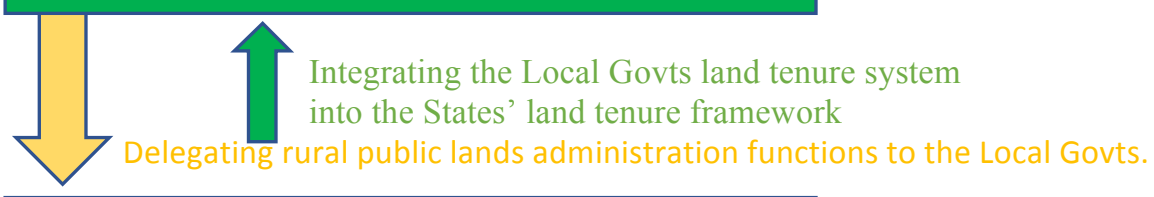

\section{LOCAL GOVERNMENTS LAND AUTHORITIES}

Integrating the community land tenure systems

into the local Govts tenure framework

\section{LOCAL/VILLAGE/COMMUNITY/KINGSHIP/FAMILY AND CUSTOMARY LAND AUTHORITIES}

\section{Source: The Author. \Bottom-up integration framework $\square$ Top-down command framework. [Delegation of functions}

Fig. i above represents the preliminary structural framework for the proposed responsible, equitable and decentralized land administration system in Nigeria. This, when finally reviewed by experts and stakeholders in Nigerian land matters and adopted by appropriate authorities would guide the development and adoption of equitable, responsible and Fit-For-Purpose land administration system in Nigeria. This would enable the proposed zonal Land Authorities articulate, develop and adopt zonespecific land administration systems that would reflect their peculiar social ideologies, accord concerned citizens the maximum benefits accruable from their land and satisfy their peculiar needs.

In this proposed land administration framework, the National Government is to retain the responsibility of establishing the common or basic standard for land administration and management for the entire country. This would include the general principles of non-discrimination, guidelines for international and large-scale land acquisitions or transactions, as well as other areas of common interest to the federating units. 
The responsibilities for the administration of public lands in urban areas will be delegated to the State Governments under a mutual arrangement that will be agreed by the stakeholders, while public lands in rural areas will be placed under the control of the Local Governments under similar arrangements. However, the responsibilities for the management and administration of natural resources in each of the six Zones that constitute the Nigerian State will be vested in the devolved Zonal Authorities under a new revenue sharing formula that will be agreed by the stakeholders.

In consideration of the important social functions performed by rural lands in general and communal lands in particular, most especially their usefulness to the livelihoods and survival of the rural populace, it is imperative that a systematic use and administrative guideline be established by each zonal authority to ensure that it meets its goal of providing for the needs of the low and vulnerable members of the society. Thus, this paper proposes for the return of allodial titles back to the original land owners and the traditional institutions, and the creation of community level land administration body that will be based on the pre-existing customary institutions. Such development would illustrate not only the government's willingness to recognize the existence and functionalities of customary institutions, but the readiness to collaborate with the local institutions for the attainment of the societal developmental goals.

\section{References}

Abdallah, M. Nurudeen, Abbas Jimoh, Azu John Chucks, Ibrahim A. Yushau, Oyew Nurudeen. 2017. "Discordant tunes over 6 geo-political Zones.” Daily Trust, Mar 29, 2017. Available at https://www.dailytrust.com.ng/discordanttunes-over-6-geo-political-zones.html. Accessed 29/04/19.

Awari, Prince. n.d. "Examining the Contemporary View that Customary Overlords and Customary Tenants is Unknown to Grundnorm for Land Administration in Nigeria." Available at <http://www.lexadvocatus.com/2017/03/examiningcontemporary-view-that.html>. Accessed 10/02/19.

Chigbu, E. Uchendu, Olaf Haub, Samuel Mabikke, Danilo Antonio and Jorge Santander Espinoza. 2017. "Tenure Responsive Land Use Planning: A Guide for Country Level Implementation." Available at $<$ https://gltn.net/2016/11/09/tenure-responsive-land-use-planning-a-guide-for-country-level-implementation/>.

Accessed 04/05/2019

Dada, Martin. 2010. "Nigeria Land Reform- the lingering debate." AfricaFiles. Available at $<\mathrm{http}$ ://www.africafiles.org/article.asp?ID=22723>. Accessed 28/03/19

Jegede, M. I, Land Law and Development (Lagos University Press, 1981)

Kunle, Aina. n.d. "Historical Evolution of Land Law in Nigeria. National Open University of Nigeria." Available at $<$ https://www.scribd.com/document/258682575/Law-421-Land-Law-I $>$. Accessed 13/04/2019.

Laws of Northern Region of Nigeria, Ch. 59, cited in THE LAWS OF NORTHERN NIGERIA 1069 (1963)

Madumere, Nelson. 2017. "Evaluating Contemporary Policy Measures on Sustainable Equitable Tenurial Rights in Nigeria." 4th Annual International Conference on Law, Economics and Politics, AICLEP \& AICEAF Cambridge Conference Proceedings, 18th -20th September 2017.

OKPALA, D. C. I, 'The Nigerian Land-Use Decree Revisited'. (1982) HABITAT INTL. Vol. 6, No. 516 , pp. 574. $<$ https://doi.org/10.1016/0197-3975(82)90024-8>. Accessed 04/12/17.

Oludayo, Gabriel Amokaye. 2011. "The Impact of Land Use Act Upon Land Rights in Nigeria.” In Robert Home (eds) Local Case Studies in African Land Law. Pretoria University Law Press, 59 - 78.

Oshio, Ehi. P. 1990. "The Indigenous Land Tenure and Nationalization of Land in Nigeria.” 10 B.C. Third World L.J. 43. Available at $<$ http://lawdigitalcommons.bc.edu/twlj/vol10/iss1/3>. Accessed 23/04/2019.

Smith, I. O. practical approach to Law of Real Property in Nigeria (2 ${ }^{\text {nd }}$. ed. Ecowatch Publication Nig. Ltd, 2007).

Williamson, Ian Philip. 2000. "Land administration 'best practice' providing the infrastructure for land policy implementation." Land Use Policy 18(4): 297- 307. DOI: 10.1016/S0264-8377(01)00021-7. 